\title{
ANALISIS RASIO KEUANGAN KOPERASI UNIT DESA (KUD) DI KABUPATEN TANJUNG JABUNG BARAT
}

\author{
Saad Murdy ${ }^{1)}$, Saidin Nainggolan ${ }^{2)}$ \\ ${ }^{1,2)}$ Dosen Jurusan Agribisnis Fakultas Pertanian Universitas Jambi \\ Email: saadmurdy@unja.ac.id
}

\begin{abstract}
Abstrak
Koperasi Unit Desa (KUD) merupakan salah satu jenis koperasi yang berada di daerah pedesaan dan menjalankan kegiatan usaha dibidang pertanian serta kehadirannya sangat dibutuhkan dan sangat membantu para anggota dan masyarakat di sekitar. Namun dengan banyaknya KUD yang berdiri hampir sebagian besar berada dalam kondisi yang kurang sehat bahkan tidak aktif lagi. Hal ini di karenakan kurangnya pengawasan dari pemerintah dan kurangnya pengelolaan yang baik di dalam manajemen keuangan KUD, sehingga penelitian ini bertujuan untuk menganalisis Rasio Keuangan KUD. Penelitian ini dilakukan pada KUD Karya Jaya, KUD Karya Kita dan KUD Sari Bumi. Metode analisis yang digunakan yaitu analisis rasio keuangan yang terdiri dari rasio likuiditas, rasio solvabilitas dan rasio profitabilitas. Data yang digunakan dalam penelitian ini adalah data laporan KUD dengan periode 5 tahun terakhir. Hasil penelitian menunjukkan bahwa rasio likuiditas, rasio solvabilitas dan rasio profitabilitas KUD di Kecamatan Merlung berada dalam kondisi yang kurang sehat karena nilai rata-rata rasio yang diperoleh KUD masih berada dibawah standar acuan perhitungan yang ada dan hanya rasio profitabilitas dengan nilai ROE diatas standar sehingga dikatakan KUD di Kecamatan Merlung berada dalam kondisi sehat didalam menghasilkan laba menggunakan modal sendiri. Maka, di dalam pengelolaan manajemen KUD harus dilakukan dengan sebaik-baiknya seperti mengembangkan jenis usaha yang dijalankan agar dapat meningkatkan pendapatan pada KUD dan pihak KUD dapat melakukan perhitungan rasio keuangan sendiri agar dapat mengontrol kondisi keuangan pada KUD dan membuat kebijakkan dengan mudah dan tepat bagi kemajuan KUD.
\end{abstract}

Kata Kunci : Koperasi Unit Desa, Rasio Keuangan, Likuiditas, Solvabilitas dan Profitabilitas.

\begin{abstract}
The Village Unit Cooperatives (KUD) is a type of cooperative that is located in rural areas and carries out business activities in the agricultural sector and its presence is very much needed and very helpful to members and the surrounding community. However, with the large number of KUD standing, most of them are in an unhealthy condition and even no longer active. This is due to the lack of supervision from the government and lack of good management in KUD financial management,so this study aims to analyze the financial ratio of KUD. This research was conducted at KUD Karya Jaya, KUD Karya Kita and KUD Sari Bumi. The analysis method used is financial ratio analysis consisting of liquidity ratio, solvency ratio and profitability ratio. The data used in this study is the KUD report data with a period of the last 5 years. The results showed that the liquidity ratio and profitability ratio of KUD in Merlung District were in an unhealthy condition because the average value of the ratio obtained by the KUD was still below the existing calculation reference standards and profitability with ROE values above the standard so it
\end{abstract}


was said that KUD in Merlung District is in a healthy condition in generating profit using its own capital. So, in the management of KUD management, it must be done as well possible, such as developing the type of business being run so that it can increase income at the KUD and the KUD can calculate is own financial ratio in order to control the financial condition of the KUD and make policies easily and precisely for progress of the KUD.

Keywords : Village Unit Cooperative, Financial Ratio, Liquidity ,Solvency ,and Profitability.

\section{PENDAHULUAN}

Koperasi merupakan salah satu lembaga yang dibuat oleh pemerintah atau swasta yang bergerak di dalam bidang ekonomi dan kehadirannya sangat dibutuhkan serta sangat membantu para anggotanya. Berdasarkan sifat keanggotaannya KUD merupakan salah satu koperasi yang turut mendukung di dalam pembangunan ekonomi di Indonesia khususnya di daerah pedesaan. Provinsi Jambi merupakan salah satu Provinsi yang ada di Indonesia yang mempunyai jenis koperasi yang beragam berdasarkan keanggotaannya yang terdiri dari Koperasi Simpan Pinjam,Koperasi Pegawai Negeri,Koperasi Pasar (KOPPAS), Koperasi Sekolah dan Koperasi Unit Desa (KUD) dan saat ini jumlah koperasi yang aktif di Provinsi Jambi berjumlah 2.550 unit dan tersebar di berbagai Kabupaten yang ada di Provinsi Jambi.

Kabupaten Tanjung Jabung Barat merupakan salah satu kabupaten yang terletak di Provinsi Jambi. Koperasi yang berdiri pada Kabupaten Tanjung Jabung Barat pada perkembangannya lebih di dominasi oleh koperasi simpan pinjam dan Koperasi Unit Desa (KUD). Koperasi Unit Desa (KUD) di Kabupaten Tanjung Jabung Barat memiliki nilai SHU sebesar Rp.1.043.012.955 dan nilai volume usaha Rp.47.039.041.883 dengan jumlah peningkatan Koperasi Unit Desa (KUD) yang sangat lamban setiap tahunnya dengan jumlah koperasi pada tahun 2016 sebanyak 368 unit koperasi dan terus mengalami peningkatan sampai pada tahun 2017 koperasi di Tanjung Jabung Barat berjumlah 372 unit.

Kecamatan Merlung merupakan salah satu kecamatan yang terletak di Kabupaten Tanjung Jabung Barat. Pada tahun 2017, Koperasi Unit Desa (KUD) di Kecamatan Merlung berjumlah 5 unit dan menjadi kecamatan nomor dua setelah Kecamatan Tebing Tinggi yang memiliki jumlah Koperasi Unit Desa (KUD) terbanyak di Kabupaten Tanjung Jabung Barat.Koperasi Unit Desa (KUD) di Kecamatan Merlung merupakan koperasi yang mengelola berbagai unit usaha meliputi TBS (Tandan Buah Segar), samprotan,simpan pinjam dan waserda. Banyaknya unit usaha yang dijalankan pada koperasi tentunya secara tidak langsung juga akan meningkatkan pendapatan KUD dan meningkatkan kemampuan KUD di dalam membayar hutang lancar yang dimilikinya. Banyaknya unit usaha yang dijalankan oleh KUD membuat pihak manajemen koperasi kesulitan di dalam mengembangkan modal dan SHU yang ada dikarenakan koperasi luput akan pengawasan pihak pemerintah sehingga KUD tersebut dipertanyakan kualitasnya di dalam menjalankan usahanya, apakah berjalan dengan lancar dan sehat.

Perkembangan Koperasi Unit Desa (KUD) dapat diketahui melalui laporan keuangan yang ada pada koperasi dengan melakukan kegiatan analisis rasio yang dapat menggambarkan apakah kegiatan yang dijalankan oleh KUD berjalan dengan lancar dan memiliki investasi yang sehat bagi koperasi tersebut. Analisis rasio terdiri dari rasio 
likuiditas,rasio solvabilitas dan rasio profitabilitas. Penelitian ini dilakukan dengan tujuan untuk menganalisis rasio keuangan KUD yang terdiri dari rasio likuiditas, rasio solvabilitas dan rasio profitabilitas di Kecamatan Merlung Kabupaten Tanjung Jabung Barat.

\section{METODE PENELITIAN}

Penelitian ini dilaksanakan di Kecamatan Merlung Kabupaten Tanjung Jabung Barat. KUD yang dijadikan sampel ditentukan secara sengaja dengan pertimbangan KUD merupakan koperasi yang aktif dan masih menjalankan kegiatan unit usahanya, bergerak di dalam bidang pertanian dan rutin mengikuti rapat anggota tahunan (RAT) serta memiliki lokasi yang berdekatan sehingga menghemat waktu dan biaya.KUD yang berada di Kecamatan Merlung ada 5 KUD yang mana dari 5 KUD dipilih 3 KUD yang dijadikan sampel yaitu KUD Karya Jaya, KUD Karya Kita dan KUD Sari Bumi. Penelitian ini bertujuan untuk menganalisis laporan keuangan yang ada pada koperasi dengan periode lima tahun terakhir.

Metode analisis data yang digunakan dalam penelitian ini adalah analisis kuantitatif. Analisis kuantitatif adalah analisis yang digunakan untuk mengetahui keadaan keuangan KUD di Kecamatan Merlung menggunakan analisis rasio dengan data yang diperoleh dari data laporan keuangan yang ada dengan periode 5 tahun terakhir. Analisis rasio keuangan terdiri dari :

1) Rasio Likuiditas

a) Rasio Lancar ( Current Ratio ) $=\frac{\text { Aktiva Lancar (CurrentAssets) }}{\text { Hutang Lancar (CurrentLiabilities) }}$ X 100\%

b) Rasio Cepat $($ Quick Ratio $)=\frac{\text { Aktiva Lancar-persediaan }}{\text { Hutang Lancar }} \times 100 \%$.

c) NWC ( Net Working Capital $)=\frac{\text { persediaan }}{\text { aktiva lancar-hutang lancar }} \times 100 \%$.

d) Rasio Kas ( Cash Ratio) $=\frac{\text { Kas+Bank }}{\text { Hutang Lancar }}$ X $100 \%$

2) Rasio Solvabilitas

a) Debt to Total Asset Ratio (DAR) $=\frac{\text { Total Utang }}{\text { Total Aktiva }}$ X 100\%

b) Debt to Total Equity Ratio (DER) $=\frac{\text { Total Utang }}{\text { Modal Sendiri }} \times 100 \%$

3) Rasio Profitablitas

a) Return On Asset (ROA) = $\frac{\text { Laba Sebelum Pajak }}{\text { Total Aktiva }}$ X 100\%

b) Return On Equity (ROE) = $\frac{\text { Laba Sesudah Pajak }}{\text { Total Ekuitas }}$ X 100\%

C) Return On Investment $(\mathrm{ROI})=$

$\frac{\text { Laba Sesudah Pajak }}{\text { Total Aktiva }}$ X 100\%

3. HASIL DAN PEMBAHASAN

Analisis Rasio Keuangan Koperasi Unit Desa (KUD) di Kecamatan Merlung

Setelah mengetahui keadaan KUD di daerah penelitian dan kinerja keuangan KUD, hal yang perlu dilakukan selanjutnya adalah menganalisis rasio keuangan KUD yang dilakukan melalui pendekatan rasio keuangan. Herry (2012) mengatakan bahwa rasio keuangan merupakan salah satu alat analisis keuangan yang paling banyak 
digunakan,dimana dalam perhitungan rasio ini menggunakan perhitungan aritmatika sederhana yang dapat di interprestasikan, dimana setiap perhitungan rasio akan jauh lebih bermanfaat jika dibandingkan dengan hasil perhitungan rasio tahun sebelumnya. Perhitungan rasio keuangan ini menjadi tolak ukur untuk melihat kesehatan KUD di Kecamatan Merlung yang tidak cukup digambarkan dari laporan keuangan saja. Rasio keuangan yang digunakan adalah rasio likuiditas,rasio solvabilitas dan rasio profitabilitas.

Tabel 1 . Rata - Rata Perkembangan Rasio Likuiditas KUD Daerah Penelitian Tahun 2015-2019

\begin{tabular}{lcccc}
\hline $\begin{array}{l}\text { Nama } \\
\text { KUD }\end{array}$ & $\begin{array}{c}\text { Rasio Lancar } \\
(\mathbf{\%})\end{array}$ & $\begin{array}{c}\text { Rasio Cepat } \\
(\boldsymbol{\%})\end{array}$ & $\begin{array}{c}\text { NWC } \\
(\mathbf{\%})\end{array}$ & $\begin{array}{c}\text { Rasio Kas } \\
(\mathbf{\%})\end{array}$ \\
\hline Karya Jaya & 132.46 & 125.68 & 21.21 & 85.89 \\
Karya Kita & 55.36 & 46.70 & -9.64 & 15.08 \\
Sari Bumi & 126.55 & 107.71 & 21.56 & 111.70 \\
\hline Kecamatan & 104.79 & 93.36 & 11.05 & 70.89 \\
\hline
\end{tabular}

Dilihat dari rasio likuiditas adalah rasio yang menunjukkan kemampuan perusahaan untuk memenuhi kewajiban finansial yang berjangka pendek dan tepat waktu (Barus et al,2017). pada Tabel 1 menunjukkan bahwa rata - rata rasio lancar KUD adalah sebesar 104,79\%. Artinya koperasi memiliki aktiva lancar sebesar 104,79\% dari hutang lancar, dengan kata lain bahwa setiap Rp.100 hutang lancar mampu dijamin oleh aktiva lancar sebesar Rp.104,79 aktiva lancar. Rasio lancar pada KUD di Kecamatan Merlung berada dalam kondisi yang kurang sehat di dalam menjamin hutang dengan aktiva lancar, karena nilai standar acuan 200\%. Jika dibandingkan dengan penelitian Wahyuningsih (2018) yang memiliki rata-rata rasio lancar sebesar 108,43\% maka KUD di Kecamatan Merlung berada dalam kondisi yang kurang sehat di dalam menjamin hutang lancarnya menggunakan aktiva lancar dikarenakan nilai rata-rata perkembangan rasio lancar berada dibawah standar acuan yang ada. Rata-rata nilai perkembangan rasio lancar KUD Daerah Penelitian pada 5 tahun terakhir dapat dilihat Gambar 1.

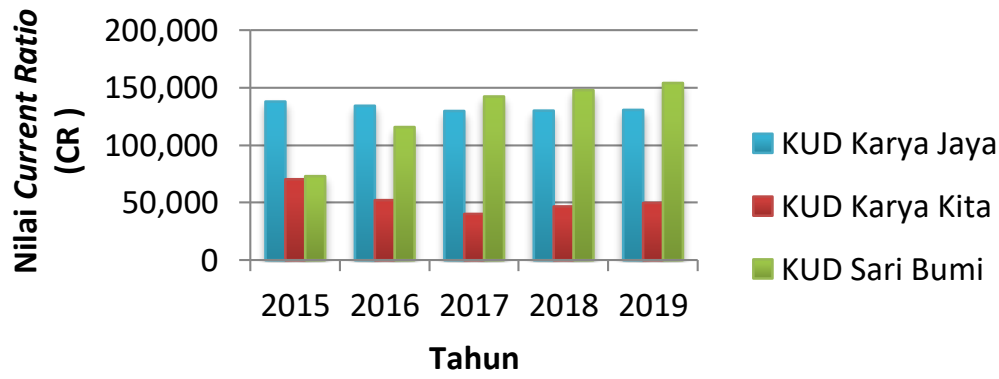

Gambar 1. Diagram Perkembangan Nilai Rasio Lancar KUD Daerah Peneltian Tahun 2015-2019

Gambar 1 menunjukan bahwa perkembangan nilai rasio lancar (current ratio) KUD cenderung mengalami fluktuasi. Pada KUD Karya Jaya dan KUD Karya Kita untuk tahun 2016 sampai 2017 mengalami penurunan nilai rasio lancar (current ratio) dan pada tahun 2018 kembali mengalami peningkatan nilai rasio lancar (current ratio). Berbeda pada KUD Sari Bumi yang pada 5 tahun terakhir nilai rasio cepat (current ratio) mengalami peningkatan. 
Rata-rata rasio cepat, KUD daerah penelitian sebesar 93,36\%. Artinya setiap Rp.100 utang lancar dapat dijamin oleh aktiva lancar sebesar Rp.93,36 tanpa memperhatikan persediaan. KUD di Kecamatan Merlung bearada dalam kondisi yang kurang sehat, karena berada dibawah standar acuan yaitu 200\%. Jika dibandingkan dengan hasil penelitian Khorutunnisak (2008) yang memiliki nilai rata-rata nilai rasio cepat sebesar 203,69\%, maka KUD di Kecamatan Merlung berada dalam kondisi yang kurang sehat karena kUD belum mampu membayar hutang lancarnya menggunakan aktiva yang dimilikinya tanpa memperhatikan persediaan karena nilai rasio cepat berada di bawah standar acuan yang ada. Rata-rata nilai perkembangan rasio cepat KUD di Kecamatan Merlung pada 5 tahun terakhir dapat dilihat Gambar 2.

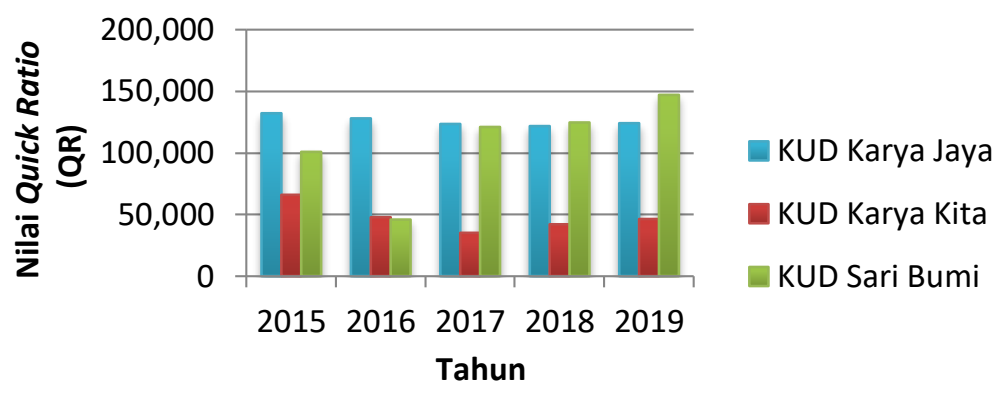

Gambar 2. Diagram Perkembangan Nilai Rasio Lancar KUD Daerah Penelitian Tahun 2015-2019

Gambar 2 menunjukan bahwa perkembangan nilai rasio cepat (Quick Ratio) KUD umumnya cenderung fluktuasi. Dimana pada KUD Karya Jaya dan KUD Karya Kita pada tahun 2016 sampai 2017 mengalami penurunan nilai rasio cepat (Quick Ratio) dan pada tahun 2018 sampai 2019 mengalami kenaikan nilai rasio cepat (Quick Ratio) kembali. Berbeda pada KUD Sari Bumi yang mana pada tahun 2016 mengalami penurunan nilai rasio cepat (Quick Ratio) tetapi pada tahun 2017 sampai 2019 terus mengalami peningkatan hingga melebihi nilai rasio cepat (Quick Ratio) pada KUD Karya Jaya.

Rata-rata Net Working Capital (NWC), KUD daerah penelitian sebesar 11,05\%. Artinya setiap Rp.100 modal kerja dijamin oleh persediaan sebesar Rp.11,05. Jika dibandingkan dengan hasil penelitian Gevinanda (2017) yang memiliki rata-rata net working capital (NWC) Sebesar 86,67\% maka kondisi KUD yang ada di Kecamatan Merlung ini berada dalam kondisi yang sangat kurang sehat dalam perputaran kerjanya karena nilai Inventory to net working capital (NWC) yang di peroleh sangat jauh dibawah standar acuan yang telah tetapkan yaitu 100\%. Rata-rata nilai perkembangan Net Working Capital (NWC) KUD Daerah penelitian pada 5 tahun terakhir dapat dilihat Gambar 3.

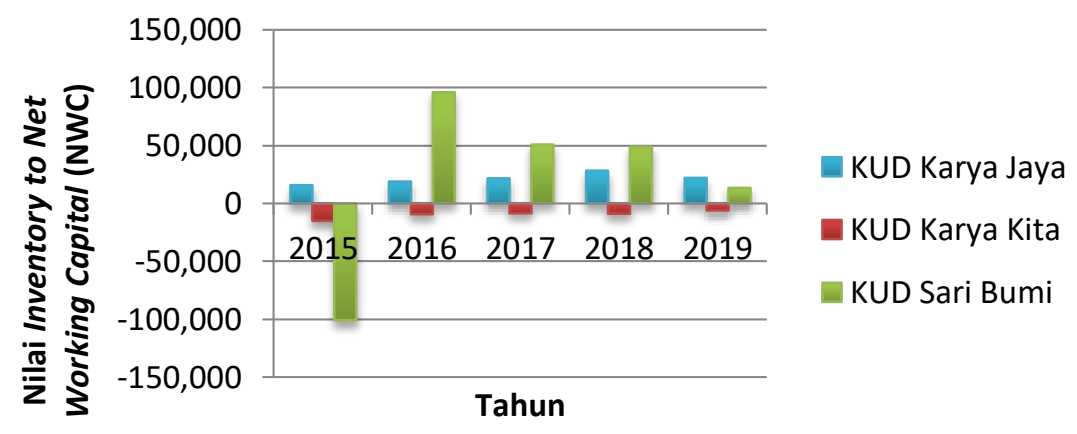

Gambar 3. Diagram Perkembangan Nilai Net Working Capital (NWC) 
Gambar 3 menunjukan bahwa perkembangan nilai Inventory to Net Working Capital (NWC) cenderung mengalami fluktuasi setiap tahunnya dan berada pada kondisi yang kurang sehat. Bahkan pada KUD Karya Kita nilai Inventory to Net Working Capital (NWC) berada pada nilai yang negatif. Hal ini menunjukkan bahwa nilai Inventory to Net Working Capital (NWC) pada koperasi dibawah 100\% dan berada dalam kondisi yang buruk.

Rata-rata rasio kas (Cash Ratio), KUD daerah penelitian sebesar 70,89\%. Artinya setiap Rp.100 hutang lancar yang dimiliki KUD mampu dijamin oleh kas dan simpanan bank sebesar Rp.70,89. Jika dibandingkan dengan hasil penelitian Gevinanda (2017) yang memiliki nilai rata-rata rasio kas sebesar 70,60\% maka KUD di Kecamatan Merlung memiliki kondisi yang sama dengan kondisi KUD pada penelitian Gevinanda (2017). Dimana KUD berada dalam kondisi yang kurang sehat di dalam menjamin hutang lancarnya dengan kas dan simpanan bank yang dimilikinya karena rata-rata perkembangan rasio kasnya berada dibawah standar acuan yang ada yaitu 200\%. Rata-rata nilai perkembangan cash rasio KUD Daerah penelitian pada 5 tahun terakhir dapat dilihat Gambar 4.

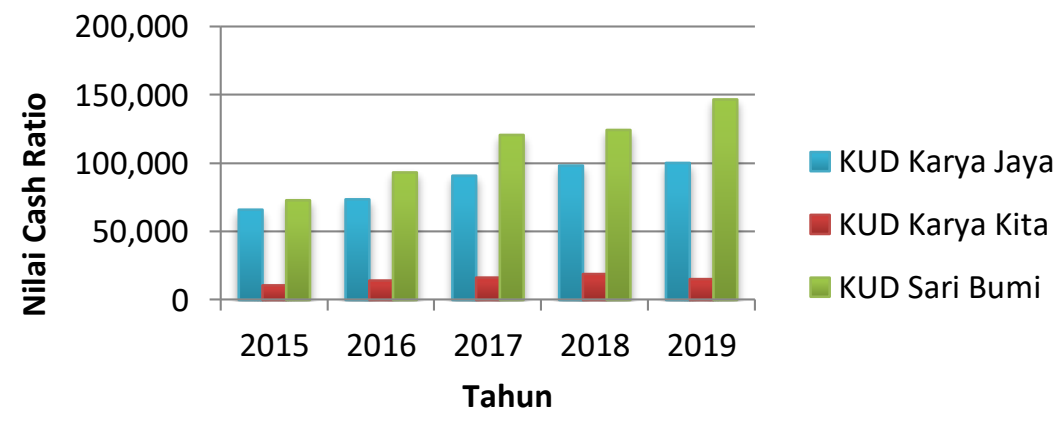

Gambar 4. Diagram Perkembangan Nilai Cash Ratio KUD Daerah Penelitian Tahun 2015-2019

Gambar 4 menunjukan bahwa perkembangan cash ratio KUD cenderung mengalami fluktuasi khususnya pada KUD Karya Karya Kita. Pada tahun 2016 sampai 2018 mengalami peningkatan akan tetapi pada tahun 2019 mengalami penurunan sementara untuk KUD Karya Jaya dan KUD Sari Bumi nilai Cash Ratio selam 5 tahun terakhir mengalami peningkatan setiap tahunnya.

KUD dalam menjalankan usahanya tentunya tidak terlepas dari hutang yang harus dibayarkan kepada pihak lain. Untuk mengukur kemampuan KUD di dalam melunasi semua kewajibannya maka digunakan perhitungan rasio solvabilitas. Rasio solvabilitas yaitu rasio untuk mengetahui kemampuan KUD untuk membayar kewajiban jangka panjang (Tumarjiyanto dan Salman,2014). Untuk melihat perbandingan rata-rata rasio solvabilitas KUD Daerah Penelitian dapat dilihat Tabel 2. 
Tabel 2. Rata - Rata Perkembangan Rasio Solvabilitas KUD daerah Penelitian Tahun 2015-2019

\begin{tabular}{lcc}
\hline Nama KUD & $\begin{array}{c}\text { Debt to Total Asset Ratio } \\
(\text { DAR })\end{array}$ & $\begin{array}{c}\text { Debt to Total Equity Ratio } \\
(\mathbf{O E R})\end{array}$ \\
& 29.51 & $(\%)$ \\
\hline Karya Jaya & 74.18 & 108.48 \\
Karya Kita & 54.30 & 450.15 \\
Sari Bumi & 52.66 & 68.77 \\
\hline Kecamatan & & 209.13 \\
\hline
\end{tabular}

Tabel 2 menunjukkan bahwa rata-rata perkembangan Debt To Total Asset Ratio (DAR) KUD yaitu sebesar 52,66\%. Artinya setiap Rp.100 aktiva yang diperoleh KUD digunakan untuk menjamin total hutang sebesar Rp.52,66. Jika di bandingkan dengan hasil penelitian Abdullah (2010) yang memiliki rata-rata Debt To Total Asset Ratio (DAR) sebesar 181,38\% maka KUD yang ada di Kecamatan Merlung berada pada kondisi yang kurang sehat karena jumlah aktiva yang dimiliki KUD hampir separo yang dijadikan jaminan dan rata-rata perkembangan Debt to Total Asset Ratio (DAR) melebihi nilai standar acuan yang telah ditetapkan. Dimana untuk rata-rata perkembangan Debt To Total Asset Ratio (DAR), semakin kecil nilainya maka semakin sehat KUD tersebut.Rata-rata nilai perkembangan Debt to Total Asset Ratio (DAR) KUD Daerah Penelitian pada 5 tahun terakhir dapat dilihat Gambar 5.

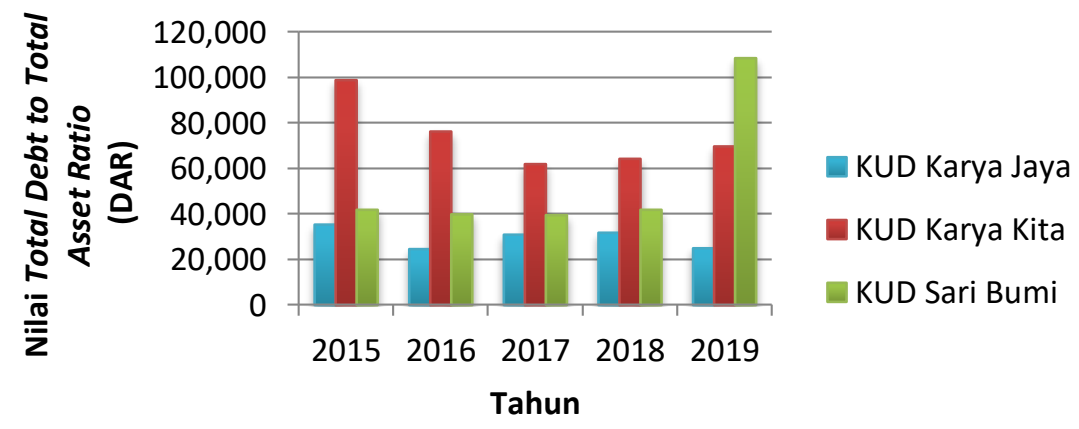

Gambar 5. Diagram Perkembangan Nilai Debt To Total Asset Ratio (DAR) KUD Daerah Penelitian Tahun 2015-2019

Gambar 5 menunjukan bahwa nilai Total Debt to Total Asset Ratio (DAR) KUD selama 5 tahun terakhir cenderung mengalami fluktuasi. Dimana pada tahun 2016 sampai 2017 mengalami penurunan nilai Total Debt to Total Asset Ratio (DAR) dan pada tahun 2018 sampai 2019 kembali mengalami kenaikan.

Rata-rata perkembangan Debt To Total Equity Ratio (DER), KUD daerah penelitian sebesar 209,13\%. Artinya setiap Rp.100 modal pada KUD digunakan untuk menjamin total hutang sebesar Rp.209,13. Jika dibandingkan dengan hasil penelitian Hidayah (2016) yang memiliki rata-rata Debt to Total Equity Ratio (DER) sebesar 67,78\% maka KUD di Kecamatan Merlung berada dalam kondisi yang kurang sehat. Dimana nilai rata-rata Debt to Total Equity Ratio (DER) melebihi standar acuan yaitu $\leq 40 \%$. Dimana untuk Debt to Total Equity Ratio (DER) semakin kecil nilai rata-rata yang didapatkan maka semakin sehat kondisi koperasi di dalam menjamin seluruh hutang dengan modal yang dimilikinya. Rata-rata nilai perkembangan Debt to Total Equity Ratio (DAR) KUD daerah penelitian pada 5 tahun terakhir dapat dilihat Gambar 6. 


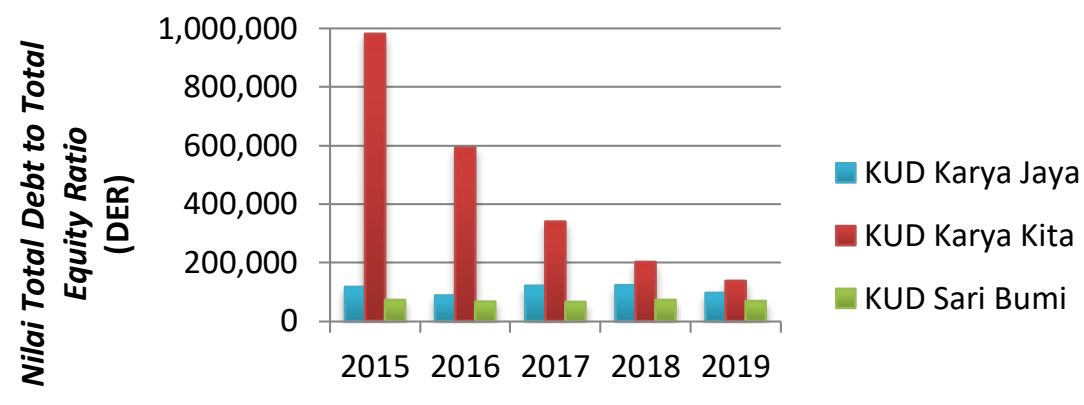

Gambar 6. Diagram Perkembangan Nilai Debt To Total Equity Ratio (DER) KUD Daerah Penelitian Tahun 2015-2019

Gambar 6 menunjukan bahwa nilai Total Debt to Total Equity Ratio (DER) KUD cenderung mengalami fluktuasi selama 5 tahun terakhir. Pada tahun 2016 sampai 2017 cenderung mengalami penurunan nilai Total Debt to Total Equity Ratio (DER) dan pada tahun 2018 sampai 2019 kembali mengalami peningkatan.

KUD dalam menjalankan unit usaha, KUD tentunya juga mengharapkan laba yang akan diperolehnya. Untuk melihat kemampuan KUD di dalam memperoleh laba bersih atau yang dikenal dengan sisa hasil usaha (SHU) perbandingan rata-rata rasio profitabilitas KUD di Kecamatan Merlung dapat dilihat Tabel 3.

Tabel 3. Rata -Rata Perkembangan Rasio Solvabilitas KUD Daerah Penelitian Tahun 20152019

\begin{tabular}{cccc}
\hline $\begin{array}{c}\text { Nama } \\
\text { KUD }\end{array}$ & $\begin{array}{c}\text { Ratio Return On Asset } \\
\text { (ROA) }(\boldsymbol{\%})\end{array}$ & $\begin{array}{c}\text { Ratio Return On Equity } \\
\text { (ROE) } \mathbf{( \% )}\end{array}$ & $\begin{array}{c}\text { Ratio Return On } \\
\text { Investmen }(\text { ROI) } \\
(\boldsymbol{\%})\end{array}$ \\
\hline Karya Jaya & 5.51 & 17.30 & 4.85 \\
Karya Kita & 7.99 & 24.12 & 4.38 \\
Sari Bumi & 7.49 & 24.62 & 4.96 \\
\hline Kecamatan & 6.99 & 36.01 & 4.73 \\
\hline
\end{tabular}

Dilihat dari rasio profitablitas merupakan suatu model analisis yang berupa perbandingan data keuangan sehingga informasi keuangan tersebut menjadi lebih bearti (Samryn,2014). Pada Tabel 9 menunjukkan bahwa rata-rata perkembangan Ratio Return On Asset (ROA) KUD di Kecamatan Merlung yaitu sebesar 6,99\%. Artinya setiap Rp.100 modal yang di investasikan dalam total aktiva akan menghasilkan laba bersih sebesar Rp.6,99. Jika dibandingkan dengan hasil penelitian Nasution (2018) rata-rata perkembangan ratio return on asset (ROA) sebesar 9,81\% maka KUD yang ada di Kecamatan Merlung ini berada dalam kondisi yang kurang sehat di dalam menghasilkan laba bersih dari total aktiva yang di investasikan. Dimana nilai rata-rata rata-rata perkembangan Ratio Return On Asset (ROA) tidak mencapai standar acuan yang ada yaitu sebesar > 10\%. Untuk rata-rata perkembangan Ratio Return On Asset (ROA) semakin besar nilainya maka kondisi KUD juga semakin sehat. Rata-rata nilai perkembangan Ratio Return On Asset (ROA) KUD Daerah Penelitian pada 5 tahun terakhir dapat dilihat Gambar 7. 


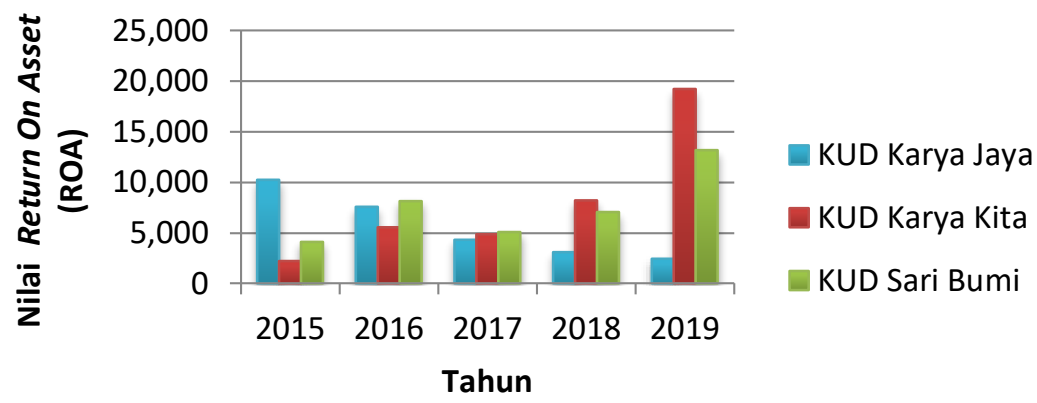

Gambar 7. Diagram Perkembangan Nilai Return On Asset (ROA) KUD Daerah Penelitian Tahun 2015-2019

Gambar 7 menunjukan bahwa bahwa nilai Ratio Return On Asset (ROA) KUD cenderung mengalami penurunan setiap tahunnya pada KUD Karya Jaya. Sedangkan untuk KUD Karya Kita dan KUD Sari Bumi setiap tahunnya cenderung mengalami fluktuasi dan pada tahun 2019 mengalami peningkatan nilai Ratio Return On Asset (ROA) yang sangat tajam dari tahun-tahun sebelumnya.

Rata-rata perkembangan Ratio Return On Equity (ROE), KUD daerah penelitian y sebesar 36,01\%. Artinya setiap Rp.100 modal yang di investasikan di dalam total equitas akan menghasilkan laba bersih sebesar Rp.36,01. Jika dibandingkan dengan hasil penelitian Gevinanda (2017) nilai Rata-rata perkembangan Ratio Return On Equity (ROE) sebesar 32,78\% maka KUD yang ada di Kecamatan Merlung ini berada dalam kondisi yang sehat karena nilai Rata-rata perkembangan ratio Return On Equity (ROE) pada KUD di Kecamatan Merlung ini melebihi nilai standar acuan perhitungan yaitu $\geq 21 \%$ sehingga dapat dikatakan KUD di Kecamatan Merlung berada dalam kondisi yang sehat di dalam menghasilkan laba menggunakan modal yang dimilikinya. Rata-rata nilai perkembangan Return On Equity (ROE) KUD Daerah Penelitian pada 5 tahun terakhir dapat dilihat Gambar 8 .

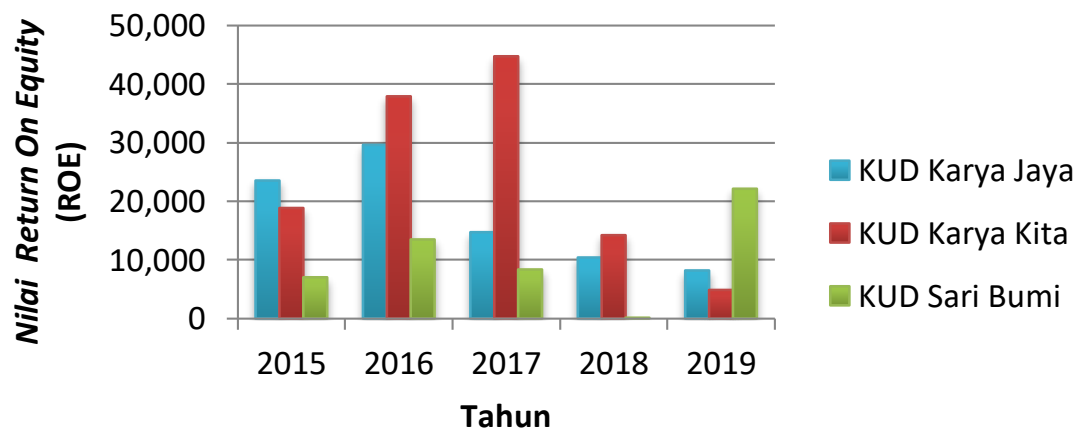

C

Gambar 8. Diagram Perkembangan Nilai Return On Equity (ROE) KUD Daerah Penelitian Tahun 2015-2019

$y$ (ROE) KUD

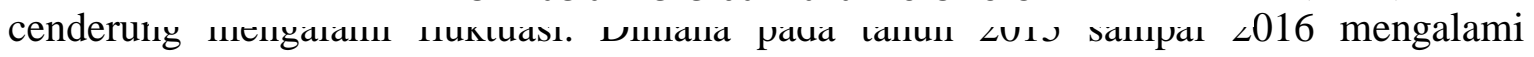
peningkatan kemudian pada tahun 2017 sampai 2019 mengalami penurunan pada KUD Karya Jaya dan pada KUD Karya Kita mengalami penurunan pada tahun 2018 sampai 2019 dan yang terakhir pada KUD Sari Bumi yang mengalami penurunan pada tahun 2017 dan pada tahun 2018 sampai 2019 kembali mengalami peningkatan.

Rata-rata perkembangan ratio Return On Investment (ROI), KUD daerah penelitian sebesar 4,73\%. Artinya setiap Rp.100 dana yang ditanamkan dalam total aktiva akan 
menghasilkan laba bersih sebesar Rp. 4,73. Jika dibandingkan dengan hasil penelitian Ambarwati (2015) yang memiliki rata-rata perkembangan ratio Return On Investment (ROI) sebesar 11,20\% maka KUD di Kecamatan Merlung berada dalam kondisi yang kurang sehat karena koperasi belum mampu menghasilkan laba dari dana yang ditanamakan dalam total aktiva dan Rata-rata perkembangan ratio Return On Investment (ROI) berada dibawah standar acuan yang ada. Rata-rata nilai perkembangan Ratio On Investment (ROI) KUD Daerah Penelitian pada 5 tahun terakhir dapat dilihat Gambar 9.

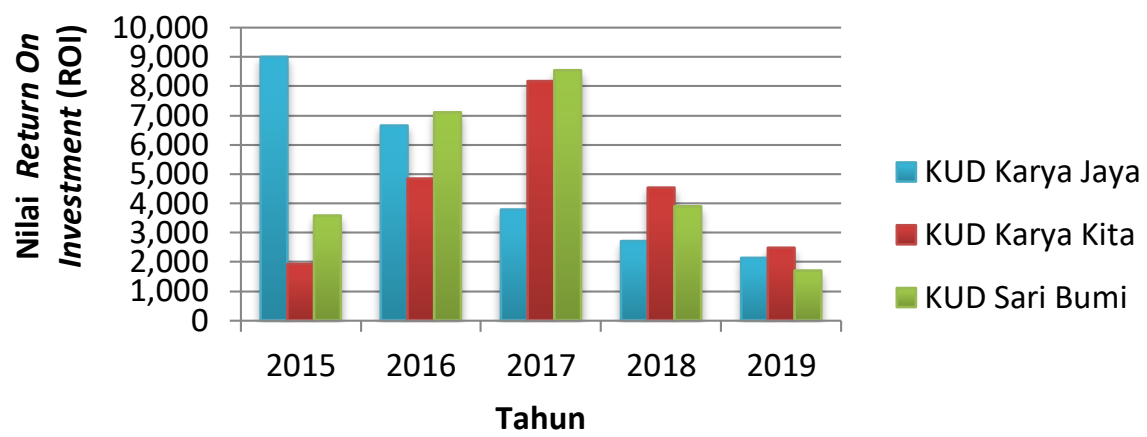

Gambar 9. Diagram Perkembangan Nilai Return On Investment (ROI) KUD Daerah Penelitian Tahun 2015-2019

Gambar 9 menunjukan bahwa nilai Ratio Return On Investment (ROI) KUD cendrung mengalami fluktuasi. Pada KUD Karya Kita dan KUD Sari Bumi, dimana pada tahun 2015 sampai 2017 mengalami peningkatan nilai Ratio Return On Investment (ROI) kemudian pada tahun 2018 sampai 2019 mengalami penurunan. Sedangkan pada KUD Karya Jaya selama 5 tahun terakhir cenderung mengalami penurunan nilai Ratio Return On Investment (ROI) setiap tahunnya.

\section{SIMPULAN}

Pada Analisis Rasio Keuangan berdasarkan perhitungan analisis rasio dapat disimpulkan bahwa pada rasio likuiditas KUD di Kecamatan Merlung yang diukur menggunakan current ratio, quick ratio, NWC, dan cash ratio menunjukkan kondisi yang kurang sehat karena berada dibawah standar acuan yang ada dan pada rasio solvabilitas KUD di Kecamatan Merlung yang diukur menggunakan debt to total asset ratio (DAR) dan debt to total equity ratio (DER) menunjukkan kondisi yang kurang sehat karena berada dibawah standar acuan yang ada serta pada rasio profitabilitas KUD di Kecamatan Merlung yang diukur menggunakan return on asset (ROA), dan Return on investmen (ROI) menunjukkan kondisi yang kurang sehat karena berada dibawah standar acuan yang ada dan hanya ratio return on equity (ROE) menunjukkan kondisi yang sehat dalam menghasilkan laba menggunakan modal sendiri karena mencapai standar acuan yang ada. Hal ini dapat menunjukkan bahwa KUD di Kecamatan Merlung berada dalam kondisi yang kurang sehat karena nilai perhitungan rasio hampir sebagian besar berada dibawah standar acuan yang ada.

\section{DAFTAR PUSTAKA}

Andani L.P.S , Rantau I.K dan Wijayanti P.U.2015. Analisis Rasio Keuangan Pada Koperasi Unit Desa (KUD) Panca Satya di Kecamatan Dawan Kabupaten Klungkung. Vol 4 (3) : 166-174. 
Ambarwati N.Y, Nainggolan Saidin dan Nurchaini D.S. 2015. Evaluasi Kinerja Keuangan Koperasi Unit Desa di Kecamatan Sungai Bahar Kabupaten Muaro Jambi. Vol. 18(1) : 83-92.

Badan Pusat Statistik. Tanjung Jabung Barat dalam Angka 2017. Badan Pusat Statistik Provinsi Jambi. Jambi.

Barus M.A, Nengah Sudjana dan Sri Sulasmiyati 2017. Penggunaan Rasio Keuangan Untuk Mengukur Kinerja Keuangan Perusahaan(Studi pada PT.Astra Otoparts,Tbk dan PT.Goodyer Indonesia,Tbk yang Go public di Bursa Efek Indonesia) Vol 44 (1) : 154-163.

Daniel Rahmad,Caska dan Makhdalena.2013.Analisis Kinerja Keuangan Koperasi Unit Desa di Kabupaten Kampar.Fakultas Keguruaan Dan Ilmu Pendidikan.Universitas Riau:Riau.

Dinas Koperasi dan UMKM.2019. Perkembangan Jumlah KUD di Provinsi Jambi Tahun 2004-2018. Dinas Koperasi dan UMKM Provinsi Jambi. Jambi.

Erica Denny.2018.Analisis Rasio Laporan Keuangan Untuk Menilai Kinerja Perusahaan PT.Kino Indonesia. Vol 2 (1) : 12-20.

Gevinanda A.P, Alamsyah Zulkifli, dan Nainggolan Saidin. 2017. Analisis Kinerja Keuangan Koperasi Unit Desa di Kecamatan Tebing Tinggi Kabupaten Tanjung Jabung Barat. Vol 20 (1) : 1-13.

Herry,S.E .2012. Analisis Laporan Keuangan.Jakarta : PT.Bumi Aksara.

Jumingan. 2011. Analisis Laporan Keuangan. Edisi ke-5. PT. Bumi Aksara, Jakarta.

Kasmir. 2014. Analisis Laporan Keuangan .Raja Grafindo Persada, Jakarta.

Khoirutunnisak. 2008. Analisis Kinerja Keuangan Bayuwanik di Kota Semarang. Skripsi. Tidak diterbitkan. Fakultas Pertanian Universitas Sebelas Maret Surakarta.Surakarta.

Munawir.S.2004.Analisis Laporan Keuangan, Edisi Ke Empat, Cetakan Ketiga Belas,Liberty, Yogyakarta.

Nasution Mutia Raisa . 2018 . Analisis Rasio Profitabilitas Sebagai Alat Untuk Menilai Kinerja Keuangan Pada PT. Jayawi Solusi Abdi Medan. Skripsi. Tidak diterbitkan. Fakultas Ekonomi dan Bisnis. Universitas Islam Negeri Sumatera Utara Medan : Medan.

Tumarjiyanto and Salman. 2014 . Analisis Kinerja Keuangan Koperasi : Studi Kasus Pada KUD Manunggal Abadi di Desa Tapung Lestari Kecamatan Tapung Hilir Kabupaten Kampar. Vol 29N (1) : 57-68.

Wahyuningsih Ni Made,Rantau I Ketut dan Yudhari I.D.A.S2018.Analisis Kinerja Keuangan KUD Werdhi Mendala Di Desa Batu Bulan Kecamatan Suka Warti Kabupaten Gianyar.Vol 7 (1) : 132-140. 